\title{
Noter i marginen
}

\section{Tilbage til rødderne}

Værdipolitik har domineret dagsordenen i Rusland siden Putins genindtræeden i præsidentembedet i foråret 2012.

I Vesten har særlig den såkaldte 'antihomolov', der forbyder seksuelle minoriteter at agitere blandt mindreårige, tiltrukket sig opmærksomhed. Men den er blot et delelement i et storstilet politisk program, som skal styrke de traditionelle, kristentortodokse familieværdier.

I flere år har det russiske underhus arbejdet med et familiekoncept, som skal indfases frem mod år 2025.

Ifølge forkvinden for Dumaens komite for familie, kvinder og børn, Jelena Mizulina, er tanken, at kirken fremover skal spille en langt større rolle i familiernes liv. Det kan for eksempel ske ved, at vielsesmyndigheden tilfalder trossamfundene, så man fremover skal giftes i en kirke, moske eller synagoge, før ægteskabet anses for retsligt bindende.

Samtidig overvejes det at indføre en føderal skat på skilsmisser og lade indbetalingerne indgå en fond til udbetaling af børnepenge for at gøre det klart for folk, at det koster staten penge, når en familie opløses. Piger under atten skal fremover ikke kunne få abort uden forældrenes tilladelse, og det skal i det hele taget påhvile sundhedsmyndighederne at tale kvinder fra abort, når de henvender sig. Desuden skal oprettes steder, hvor kvinder anonymt kan aflevere babyer op til seks måneders alderen. Målet er at reducere antallet af aborter betydeligt og gøre en familie med tre børn til en standardfamilie i Rusland.

Spørgsmålet er så, hvorfor præsident Putin, der selv blev skilt fra Ljudmila Putina for nylig, er så opsat på at gøre familien til grundstenen i samfundet?

Det har han flere gode grunde til.

For det første må man huske, at Putin kom til magten i foråret 2012 under den bølge af protestdemonstrationer, der fulgte i kølvandet på parlamentsvalget i slutningen af 2011. Så omfattende var utilfredsheden i de store byer, at det i Vesten blev diskuteret, om der var et 'russisk forår' på vej.

Det har givetvis bekymret Putin, der har besluttet sig for at konsolidere sin magt i den brede, konservative del af befolkningen; den russiske provins. Dette flertal af borgere protesterer gerne mod korruption, sultelønninger og beskæring af statslige subsidier, men aldrig mod krænkelse af mindretalsrettigheder, som de anser for at være en vestlig spe- 
cialitet. Putin er i sin tredje embedsperiode blevet deres talerør - og har dermed forhindret, at befolkningen samler sig i et fælles oprør mod elitens grådighed og privilegier.

En anden årsag til værdipolitikken er, at den er billig og flytter fokus fra landet økonomiske problemer. Den Russiske Centralbank anslog fornylig, at væksten i år kun bliver to procent, hvilket ville være meget, hvis der var tale om et europæisk land, men forsvindende lidt i sammenligning med de øvrige Brics-lande, og i hvert fald mindre end forventet.

En tredje væsentlig årsag er, at der vitterligt er brug for, at russerne får flere børn, hvis de fortsat skal kunne herske uantastet over verdens geografisk største område. De demografiske nøgletal er forfærdende: I 1993 var der 148,6 millioner russere, i 2010 var der 141,9 - på trods af en massiv indvandring fra de tidligere sovjetrepublikker. Både internationale og russiske fremskrivninger viser, at der i 2050 vil være 100,9 mio. russere tilbage, hvis trenden fortsætter uforandret. Med så få borgere kan Rusland ikke gøre krav på at være en stormagt på niveau med Kina og USA, som man ønsker.

Den fjerde grund til værdipolitikken ligger i forlængelse heraf. Putin har, siden han overtog magten $\mathrm{i}$ år 2000, ønsket at gøre Rusland til en civilisation i egen ret; en civilisation, som hverken blev betragtet som en del af Vesten eller Østen.

Derfor søger han at genoprette den kontinuitet, der blev brudt med Sovjetunionens sammenbrud. Hans nye værdipolitik er således gammel - den trækker både på traditionerne fra Sovjettiden og tsartiden.

I Sovjettiden var det ganske vist ikke kirken, men staten, der blandede sig i familielivet, men det sovjetiske samfund var ikke desto mindre stærkt konservativt. Både aborter og skilsmisser var vidt udbredte, men de var stadig tabubelagte, og homoseksualitet medfødte ligefrem fængselsstraf.

Og før da, i det 19. århundrede, stod værdikampen mellem slavofiler, som ville skærme Rusland mod det dekadente og værdirelativistiske Vesten, og zapadnikkerne, der ville reformere det i vestlig retning.

Putin kan roligt hævde, at hans værdipolitik blot er vraies valeurs de la Russie.

Derfor er han heller ikke skuffet over vestens modvilje over hans nye politik. Hvis Vesten havde reageret med ligegyldighed, ville det jo være, fordi Vesten ikke tog Rusland alvorligt. Nu bekræfter den stærke modstand blot, at Vesten forsøger at trække Rusland med sig i sit moralske fald.

Anna Libak er litteraturredaktør ved Weekendavisen. 